https://doi.org/10.31516/2410-5325.064.03

UDC 811.112.2'282.2/.3:008](045)

S. V. Chastnyk, Candidate of Philological Sciences, Associate Professor, Kharkiv State Academy of Culture, Kharkiv

inozem49@ukr.net

http://orcid.org/0000-0003-2147-4945

\title{
REGIONAL DIALECTS IN THE CULTURAL LIFE OF GERMANY
}

This paper contains an overview of online and printed sources dealing with the phenomenon of The Renaissance of Dialect in Germany, particularly with the growing use of dialect in the cultural life of the country. Special attention is paid to the problem of motivation for choosing dialect in theatre acting and rock singing. As a rule, dialect is used to mark the performer's regional identity and has symbolic value. However, aspiration for individual self-determination as well as commercial motives are also present in this process. Another issue covered in the article concerns a possible danger of "cultural separatism" caused by dialect revitalization. The overview shows that introducing modern forms into dialect music increases the popularity of local vernacular with German youth. However, the area of functioning of dialects will be, in all probability, confined to the use in everyday, private life.

Keywords: dialect renaissance, cultural life, folk theatre, folk singing, regional identity, individual identity, standard language.

С. В. Частник, кандидат філологічних наук, доцент, Харківська державна академія культури, м. Харків

\section{РЕГІОНАЛЬНІ ДІАЛЕКТИ В КУЛЬТУРНОМУ ЖИТТІ НІМЕЧЧИНИ}

Актуальність. Становлення та розвиток більшості національних держав у Європі супроводжувалися звуженням сфер функціонування регіональних діалектів. Своєрідною реакцією на нівелювання місцевих мовних та культурних особливостей стала нинішня хвиля «діалектного відродження», насамперед у Німеччині. Цілком актуальним у цьому контексті є інтерес дослідників до популярного нині використання діалектів у театральному та музичному житті ФРН та можливого впливу цього явища на соціолінгвістичну ситуацію в країні.

Мета статті - здійснити критичний аналіз сучасних поглядів на соціолінгвістичні, культурологічні та етнопсихологічні аспекти «діалектного відродження» в Німеччині.

Методологія. У розвідці застосовано методи компаративного аналізу, узагальнення та систематизації.

Результати. Дослідження німецького досвіду засвідчило, що використання діалектів у культурному житті (театр, музика, телебачення) надає місцевим говіркам реальну можливість вийти за межі побутового спілкування і навіть за межі свого регіону. Виявлено, що діалект у лінгвістичному арсеналі актора чи співака найчастіше виступає в ролі маркера його колективної регіо-нальної ідентичності і має символічну цінність. Чималу роль у виборі мови для сцени відіграє майже архетипний мотив «мовної ностальгії». Водночас діалект у репертуарі артиста використовується (свідомо чи підсві- 
домо) як інструмент індивідуального мистецького самовизначення. Аналіз німецькомовних джерел свідчить про те, що найкращим способом для діалекту здобути популярність серед молодих людей є адаптація традиційної народної музики до їхніх смаків і потреб. 3 цього приводу дослідники висловлюють обережний оптимізм щодо перспектив використання німецьких діалектів, принаймні в розмовній формі. Відзначено, що наявність місцевих діалектів у культурному житті не надає жодних підстав для розвитку «культурного сепаратизму» і не загрожує національній єдності.

Новизна. Уперше пропонується огляд друкованих і електронних публікацій стосовно мотивації, форм і перспектив використання регіональних діалектів Німеччини в культурному житті країни.

Практичне значення. Матеріали і висновки дослідження можуть бути використані у викладанні соціолінгвістичних та культурологічних дисциплін, а також під час оцінювання перспектив ужитку діалектів української мови в театральному та музичному мистецтві.

Ключові слова: відродження діалектів, культурне життя, народний театр, народний спів, регіональна ідентичність, індивідуальна ідентичність, літературна мова.

С. В. Частник, кандидат филологических наук, доцент, Харьковская государственная академия культуры, г. Харьков

\section{РЕГИОНАЛЬНЫЕ ДИАЛЕКТЫ В КУЛЬТУРНОЙ ЖИЗНИ ГЕРМАНИИ}

Представлен обзор онлайновых и печатных публикаций, в которых рассматривается феномен «диалектного ренессанса» в Германии, в частности, широкое применение диалектов в культурной жизни страны. Особое внимание уделено проблеме мотивации при выборе диалекта в театре и рок-музыке. Как правило, диалект является маркером региональной идентичности исполнителя и имеет символическую ценность. Вместе с тем, в этом процессе присутствуют стремление к индивидуальному самоопределению и коммерческие мотивы. Еще одна проблема, рассмотренная в статье, касается возможной опасности «культурного сепаратизма», вызванного возрождением диалектов. Обзор показал, что введение современных форм в диалектный песенный репертуар увеличивает популярность местных говоров среди немецкой молодежи. Несмотря на это, функционирование диалектов и в дальнейшем будет, по-видимому, ограничено бытовой сферой.

Ключевые слова: возрождение диалектов, культурная жизнь, народный театр, народная музыка, региональная идентичность, индивидуальная идентичность, литературный язык.

Problem statement. The current sociolinguistic situation in Germany, termed Dialektrenaissance (The Renaissance of Dialect), seems paradoxical. On the one hand, the standard German language (Hochdeutsch) prevails in almost all areas of public life of the country, while the role of dialects has been reduced to the use in everyday life of the rural population. Even Bavarian with its numerous native speakers has been listed in the 'UNESCO 
Atlas of Language in Danger' among other endangered languages. On the other hand, an opposite trend is taking place in cultural life: German theatre companies and music bands readily turn to local linguistic material. Singing in dialect becomes prestigious, and the fashion for «local flavor» extends beyond regional boundaries.

For researchers, The Renaissance of Dialect is an interesting multidimensional phenomenon. An analysis of existing publications on this topic makes it possible to outline some important issues of a theoretical and practical nature. The following aspects deserve particular attention:

- from the culturological point of view, The Renaissance of Dialect is a quite positive phenomenon, since performing in dialect means turning to a sometimes neglected cultural heritage; however, in the social context, the aspiration for local (regional) self-determination can be associated with the danger of «cultural separatism» and a threat to national unity;

- psychologists and ethnopsychologists searching for the deep roots of the Dialektrenaissnce will be interested in exploring motivation for the language choice (standard language vs dialect);

- sociolinguistic studies can provide an answer to the question whether the current renaissance can be instrumental in solving the problem of revitalizing local dialects.

Accordingly, the aim of this paper is to present an overview of recent online and printed publications dealing with the issues outlined above.

Previous research. The increased presence of regional dialects in today's cultural life has predominantly been explored in the broad context of the problem of dialect in the community. Special attention is paid, for example, to the impact of globalisation on local varieties of the national language (Hanke, 2010; Grijp, 2007). Numerous online publications focus on the changing public attitude towards dialect, associating this phenomenon with the growth of the regional identity (Hofsähs, 2015; Dialekt in der Gesellschaft - Baden-Württemberg, 2016; "Mir san mir", 2011). Drawing on the material of several case studies, researchers discuss several models that could explain the rise of dialect music (Grijp, 2007). A number of articles contain interesting information on the regional distribution of dialect-based cultural events in Germany as well as genres and forms of art in dialect renaissance (Hanke, 2010; Grijp, 2007). Of particular interest are works devoted to the problem of language choice (dialect or standard language) in music and theatre, i.e. the motivation to sing or act in dialect (Grijp, 2007). Worth mentioning are also some publications containing different views on the future of the current dialect revival (e.g. Dialekt in der Gesellschaft Baden-Württemberg, 2016). 
The main text. According to a survey conducted by the Institute of the German Language in 2009, 60 percent of the Germans speak dialect, mainly in the south of the country (Hanke, 2010). There are about 20 different dialects with a lot of local varieties. Most of dialect speakers live in Baden-Württemberg and Bavaria. For this reason some researchers consider the term Dialektrenaissance incorrect. Prof. Mattheier, an expert in German dialectology, argues that "...in the South there is no dialect decline, consequently, there is no dialect renaissance" (Mattheier, 1997). However, the term seems quite justified if we take into account the widening geography and the variety of genres of dialect-based artistic activities, as well as the growing number of singers, bands and theatre companies performing in dialect.

The big theatres in Germany generally avoid the vernacular. At present, specific language nuances are used in the theatre to emphasize ethnic and social differences of certain characters. At the same time, advocates of local languages revival are strongly opposed to the misuse of dialects on the stage. Winfried Kretschmann, Minister-President of Baden-Württemberg since 2011, points out: «As a sympathizer, I am not happy when dialect and the Swabians are used as a cheap means of making fun. [...] Dialect is often misused as a vehicle for funny, harmless jokes. The linguistic qualities at amateur theatres, cabarets and in comedy programmes are often below criticism. Even with the first Swabian sentence the audience bursts out laughing! As a result, a reflexively parodic attitude towards dialect develops. ... the Swabians and the Swabian are simplified, in which there is a certain condescension." (Dialekt in der Gesellschaft - Baden-Württemberg, 2016).

In contrast, dialect seem to flourish in numerous folk theatres (Volkstheatre), widely represented all over Germany. People in folk theatres consider dialect «a trump card». In their opinion, dialect theatres add an aspect to the cultural offer that cannot be served by the big houses (Hofsähs, 2015).

The following online comments give you some idea of dialect theatre geography and the reasons for choosing dialect for stage performances.

Cabaret in Saxon. Cabaret artist Uwe Steimle believes dialects contribute to comedy. «Dialects are funny in themselves,» he says. «You do not take yourself so seriously.» But humor is not the only reason why his cabaret character Günther Zieschong speaks Saxon. Steimle is a Saxon with body and soul and the Saxon tongue is part of his personality. The sense of homeland and belonging are important to him. «Those who speak Hochdeutsch do not want to be identified,» says Steimle, who finds the standard language cold and distant. Dialects, on the contrary, are authentic and warm. As Johann Wolfgang von Goethe once put it, «Every province loves its dialect, for it is the very element in which the soul draws its breath.» 
Theatre in Bavarian. Theatre director Christian Stückl is bilingual, he speaks both standard German and Bavarian. For him dialect has much to do with comedy. «Bavarian is the liveliest language the way one speaks,» he says. They've had a full house on a regular basis for five years. Every year, the plays in Bavarian attract four times as many viewers as plays in Hochdeutsch (Hanke, 2010).

The dialects in the Plattdeutsch area had until recently been seen as disappearing. Even in the period before and after the Second World War, they were considered by many to be superfluous or as a barrier to communication. However, such theatres as Millowitsch theatre, Ohnsorg theatre, Komödienstadl and an increasing number of music groups and singers with young target audience tried to make the dialect acceptable again. (Wikipedia)

Even the Bavarians, who are lucky to speak the country's most popular dialect (at least that's what the polls reveal every year) are making an effort to keep it alive. From mid-July to mid-August, 14 actors, all Bavarian speakers, but mostly living in the linguistic diaspora, learn to use this language on stage in the «Summer Academy for Bavarian People's Show». More than 80 candidates applied for the 14 places. One of the alumni of the Summer Academy is the director Marcus Rosenmüller. At the Filmfest in Munich, his new film, Räuber Kneißl, is currently on. Authentic dialect (Volldialekt) is spoken in the movie. Of course, not all viewers will understand every word, but nevertheless there are no subtitles. Producer Susanne Hildebrand explains it this way: «The dialect is the blood of this film.» (Stolz, 2008)

As to the so-called "dialect purity", there are two entirely different views. Some critics believe that dialect on the stage or in a film should be 'pure', i.e. authentic, real. Others insist that the dialogues should be adapted so that a broader audience could understand. A well-known case is often cited: when Gerhart Hauptmann in the 1880s put on the stage his famous plays in the local dialect of Silesia, the audience protested and demanded translation into standard German because the text was utterly incomprehensible to them.

Modern attempts at adapting dialect texts to the needs of Hochdeutsch speakers can be illustrated by the case of Dahoam is Dahoam.

Dahoam is Dahoam is a very popular German television series successfully broadcast since 2007 with over 2000 episodes. The characters speak the Bavarian dialect (with some adjustments to standard German). The series was in the focus of public criticism, especially at the beginning of its broadcast, because Bairisch spoken in the series represents only an adapted, simplified form of the dialect. In fact, essential elements of Bavarian are attenuated or omitted in the scripts (Wikipedia). The trend towards regionality is also reflected in the media: More and more radio and television 
hosts speak a mixed form of dialect and standard German. In the opinion of many critics, the worst thing for the dialect is when it is spoken badly or wrongly. "This is certainly not a dialect but neither is it Hochdeutsch!" ("Mir san mir", 2011).

Very popular in Germany is the so-called Mundartmusik (dialect music). The term refers to music, the lyrics of which are written in a local dialect instead of the standard language. The use of vernaculars is particularly evident in Volksmusik (traditional folk music) and, much less so, in Volkstümliche Musik (modern versions of folk music), but is not limited to these genres. The use of dialect is also characteristic of Mundartrock (Dialect rock), Neue Volksmusik (New folk music), etc. Neue Volksmusik describes the mix of traditional German folk music (Volksmusik) with newer genres such as jazz, contemporary folk, hiphop, and/or rock (Wikipedia). By skilfully combining various genres, a dialect singer can present an old song in a new, interesting light. In the opinion of Grijp (2007), music is the most successful genre of the dialect renaissance because it uses contemporary forms of expression in addition to traditional dialect. By employing contemporary, international music styles, dialect music has the potential to reach a young audience, whereas the other forms often appeal more to older people. (Grijp, 2007).

Volkstümliche Musik is a modern popular derivation of the traditional Volksmusik genre of German-speaking countries. Though it is often marketed as Volksmusik, it differs from traditional folk music in that it is commercially performed by celebrity singers and concentrates on newly created sentimental and cheerful compositions with lyrics in dialect (Wikipedia). As a subject of the Schlager genre, Volkstümliche Musik evolved from folklore roots and today receives much attention in the public broadcasts. Volkstümliche songs transmit values emphasizing Heimat (homeland). It is seemingly 'authentic' folk music that creates a sense of 'artificial identity' (Dialekt \& Musik, 2017).

Grijp (2007) associates the popularity of dialect music in a given part of the country with the extent to which dialect is spoken there. For instance, in some provinces of the Netherlands where very little dialect is spoken, music in dialect is almost completely absent. (Grijp, 2007). In this respect, one can note a direct relationship between the spread of dialect music in Bavaria and the popularity of local dialects in this Bundesland. There seem to be no exact numerical data as to the number of Bavarian rock bands and individual singers performing in dialect. Wikipedia, for example, contains links to 76 sites of the most popular performers singing in Bavarian. All parts of the province seem to be represented, e.g. Die Spider Murphy Gang, Werner Schmidbauer \& Konstantin Wecker in Munich; Die Biermösl Blosn in the Southwest; Die Cubaboarischen in Oberland (Highland); Claudia Koreck and LaBrassBanda in Chiemgau; Hans Söllner in the Southeast; Haindling in Niederbayern (Low Bavaria); D'Raith Sisters in Oberpfalz. 
In the opinion of most critics, the current rise of dialect-based theatre and music in Germany is inseparable from the changing attitude towards local language varieties. More and more people believe that dialects as part of the country's cultural heritage are worth preserving. However, the main reason for the attempts to revitalize dialects seems to be the spread of antiglobalist sentiments in Western society. People are tired of uniformity, they want to be different, they want to be themselves. Hence the eloquent motto of the Bavarians: "Mia san mia" meaning "We are who we are" or "Take us or leave us". Many yearn for a "smaller world" where they belong. They identify themselves with the smaller units, the regions they really know, rather than with the world or the state (Stolz, 2008). Researchers point out that It is dialect that lends regional music its individual character, together with the frequent use of subjects with a regional flavour (Grijp, 2007). Thus, speaking and singing in dialect becomes a sort of regional identity mark.

German sociologists call this phenomenon "die Suche nach Heimat" (the search for home). It is described as the radical narrowing of the wide world around us caused by the desire to live in harmony with oneself and nature. By analogy with Heimweh (homesickness) H. Wicker even coined the term Sprachweh which could be loosely interpreted as the feeling of longing for the half-forgotten language of one's childhood. Mobile Heimat (mobile home) is another term for one's native dialect denoting nostalgic, warm sentiments that you take with you wherever you go for the rest of your life (Dialekt in der Gesellschaft - Baden-Württemberg, 2016). Thus, one's sprachliche Heimat (linguistic homeland) gradually loses its geographical bearings and transforms into a mental spaceless and timeless construction, a spiritual phenomenon not unlike Japanese furusato.

In public life, dialect can be used for utilitarian purposes. The advertising slogan “Wir können alles. Außer Hochdeutsch!" "We can do everything. Except Hochdeutsch!") is well known in Baden-Württemberg. This expression serves to emphasize and exaggerate the Land's linguistic uniqueness; at the same time, it is part of a campaign advertising the province's success in business and science, and the high quality of life (Dialekt in der Gesellschaft - BadenWürttemberg, 2016). Here opposition to the standard language serves both as a regional identity mark and tourist attraction in the same way as Gaelicand Irish-language road signs in Scotland and Ireland.

Similar dual motivation for language choice can be seen in popular music. Martin Stokes, an expert in ethnomusicology, stresses the importance of music in the construction of ethnic identities, both national and regional (Stokes, 1997). Music, in combination with dialect, is an appropriate tool for expressing regional identity. At the same time, such music offers entertainment that people with little or no understanding of dialect can also enjoy (Grijp, 2007). 
It has been noticed, however, that singing in dialect is not necessarily a sort of manifestation of local patriotism. Suppose a young band from Lower Franconia who dream of popularity ask themselves: how are their songs to be noticed and perceived among hundreds of thousands of similar products? They need some peculiarity, some distinctive features, identity. And what is better than their own dialect which might be internationally exotic and regionally authentic? (Dialekt \& Musik, 2017). In this connection Grijp (2007) remarks: “... the question remains as to whether the articulation of regional identity is in fact what dialect music is striving for. Rather, it would appear that musicians want to express their personal identity with the help of dialect as a collective given". The researcher goes on to say that "... none of the singers to our knowledge has ever mentioned regional identity as the motivation behind his or her decision to sing in dialect. For the artists, it was primarily a desire for a personal style and an effective means of expressing themselves that prompted this decision, together with the positive response of the audience." (Grijp, 2007)

Researchers note a direct connection between the growing role of dialect in the cultural life and the rise of their status, "... when people began writing, performing and singing in dialect." (Grijp, 2007). Are we to infer from this fact that dialect revitalization necessarily is a threat to national unity? After all, it was the emergence and spread of Hochdeutsch that had once contributed to unification of Germany. A discussion in the Welt online newspaper (2010) revealed strong differences of opinions on this subject. One of the contributors argues: "As long as dialect remains a private matter, there are no objections. But why should state resources be spent on stopping a language development caused by historical reasons? /.../ Instead of supporting an artificial competition, the authorities had better invest more money into teaching [standard] German at school." Others advocate teaching dialect (Plattdeutsch) at school and are not against elevating its status to an official language in Low Saxony (Dialekte: Mundart muss Privatsache bleiben, 2010).

Talking of the "dialect/standard language" relationship, it would be interesting to know the opinion of dialect performers themselves. Take, for instance, Plögert, who sings in Swabian dialect. Although he does not speak it in everyday life, the singer is convinced that "...we should communicate as much Swabian as possible and as much standard German as necessary", speaking therefore in support of situational bilingualism. Most regional officials and public figures share this point of view. Johannes Kretschmann puts it this way: Dialect is no competitor to the standard language; it is a complement (Dialekt in der Gesellschaft - Baden-Württemberg, 2016). Thus, a sort of linguistic "peaceful co-existence", i.e. division of areas of 
functioning seems to be the best solution in this case: dialect in private life and standard language in official communication.

Conclusion. One of the most vivid manifestations of the current revitalization of local dialects in Germany is its use in the cultural life of the country, predominantly in the theatre and music. The motivation for singing or acting in dialect instead of standard German ranges from a sense of regional identity to the aspiration for personal self-determination. Whatever the reasons for such choice, this practice elevates the prestige of endangered dialects and contributes to their preservation, at least in spoken form. Adopting dialect music to the tastes of young people seems promising for the future survival of local varieties of German. The growing use of dialect in cultural life has nothing to do with "cultural separatism" and does not threaten national unity.

\section{References}

Dialekt in der Gesellschaft - Baden-Württemberg. (2016, 20. Oktober). Retrieved from https://www.baden wuerttemberg.de/.../161020_Kretschmann Vortrag_Dialekt_in_der_Gesellschaft.pdf. [In German].

Dialekt \& Musik (2017). Retrieved from udi.germanistik.uni-wuerzburg.de/.../ Lehrerhandreichung Über-jedes-Bacherl-geht-a-Brückerl.pdf [In German]. Dialekte: Mundart muss Privatsache bleiben. (2010). WELT, 20. Juni 2010. Retrieved from https://www.welt.de > Debatte > Kommentare. [In German].

Hanke, K. (2010). Dialekte in der deutschen Kulturszene - Goethe-Institut. Retrieved from www.goethe.de/ins/gb/lp/prj/mtg/.../de6250720.htm. [In German].

Hofsähs, U. (2015). Sprachforschung: Der Dialekt stirbt aus — außer in Köln. WELT, 20. Mai 2015. Retrieved from www.welt.de/.../Der-Dialekt-stirbtaus-ausser-in-Koeln.html. [In German].

Grijp, L.P. (2007) Singing in Dutch Dialects: Language Choice in Music and the Dialect Renaissance. In P. Margry, \& H. Roodenburg (Eds.). Reframing Dutch Culture. Between Otherness and Authenticity (pp. 225-243). Aldershot: Ashgate. [In English].

Mattheier, K. J. (1997). Dialektverfall und/oder Dialektrenaissance? Varietäten des Deutsches: Regional- und Umgangssprachen. Retrieved from https://www.degruyter.com/viewbooktoc/product/13374. [In German]. "Mir san mir" (Wir sind wir) - das Comeback der deutschen Dialekte. (2011). Retrieved from https://www.alumniportal-deutschland.org/deutschland/.../ das-comeback-der-deutschen-dialekte/- 2011. [In German].

Stokes, M. (1997). Ethnicity, Identity and Music: The Musical Construction of Place. Oxford, Berg Publishers. [In English].

Stolz, M. (2008). Sprache: die neue Dialektik. Zeit online, 18. Juni 2008. Retrieved from https://www.zeit.de > gesellschaft. [in German].

Надійшла до редколегії 10.05.2019 р. 